\title{
Application of BS4-Enzyme on the Methane Production from Mixture of Cattle Manures and Waste Paper
}

\author{
Haryati $\mathrm{T}^{1}$, Sinurat $\mathrm{AP}^{1}$, Listian $\mathrm{B}^{2}$, Hamid $\mathrm{H}^{1}$, Purwadaria $\mathrm{T}^{1,2}$ \\ ${ }^{1}$ Indonesian Research Institue for Animal Production, Ciawi PO Box 221, Bogor Indonesia \\ ${ }^{2}$ Faculty of Biotechnology, Atma Jaya Catholic University of Indonesia, Jakarta Indonesia \\ E-mail: purringcats2001@yahoo.com.au
}

(received 10-10-2016; revised 30-11-2016; accepted 05-12-2016)

\begin{abstract}
ABSTRAK
Haryati T, Sinurat AP, Listiani B, Hamid H, Purwadaria T. 2016. Aplikasi enzim-BS4 dalam produksi biogas media campuran kotoran sapi dan koran bekas. JITV 21(4): 238-243. DOI: http://dx.doi.org/10.14334/jitv.v21i4.1524

Koran bekas adalah sampah yang dapat diubah menjadi biogas melalui fermentasi anaerob. Tujuan dari penelitian ini adalah untuk membandingkan produksi gas total dan metana pada substrat campuran feses sapi dan koran bekas masing-masing sebagai inokulum dan substrat dengan penambahan enzim dan tanpa penambahan enzim. Enzim BS4 diproduksi di Balai Penelitian Ternak (Balitnak) dengan menumbuhkan Eupenicillium javanicum BS4 pada bungkil kelapa. Terdapat tiga perlakuan dalam penelitian ini, yaitu: 30\% BK dari feses (M30); $15 \%+15 \%$ koran bekas (MP30); dan MW30- ditambahkan dengan $3 \mathrm{ml}(0,42$ U/g BK) enzim (MPE30) Persentase penambahan substrat koran diperhitungkan terhadap bobot kering feses dan setiap perlakuan diulang lima kali. Produksi gas total dan metana diukur tiap minggu. Kehilangan bahan kering (KBK) diukur selama 5 minggu fermentasi. Analisis pengaruh perlakuan terhadap produksi gas dan metana dilakukan dengan rancang acak lengkap pada setiap minggu. Uji beda nyata ditentukan dengan LSD. Penambahan enzim dan koran meningkatkan produksi gas. Produksi gas dan metana tertinggi secara nyata $(\mathrm{P}<0,05)$ didapat dari perlakuan MP30 dan MPE30 dibandingkan dengan M30 pada minggu kelima. Penambahan enzim secara sangat nyata meningkatkan produksi metana pada minggu pertama. Produksi gas total dan metana terhadap KBK paling efektif secara nyata ditunjukkan pada perlakuan MPE30. Enzim BS4 dapat digunakan untuk mempercepat dan meningkatkan efisiensi transformasi campuran koran dan feses menjadi metana yang dapat digunakan sebagai biogas.
\end{abstract}

Kata Kunci: Metana, Enzim-Fibernolitik, Koran Bekas, Feses Sapi

\section{ABSTRACT}

Haryati T, Sinurat AP, Listiani B, Hamid H, Purwadaria T. 2016. Application of BS4-enzyme on the methane production from mixture of cattle manures and waste paper. JITV 21(4): 238-243. DOI: http://dx.doi.org/10.14334/jitv.v21i4.1524

Cellulose from abundant newspaper waste could be transformed into methane through anaerobic fermentation. This research was carried out to compare the gas production including methane between samples containing feces and waste paper mixture as inoculum and substrate, respectively and added with and without BS4 enzyme. The enzyme was produced in Indonesian Research Institute for Animal Production (IRIAP) by growing Eupenicillium javanicum BS4 in coconut meals. There were three treatments, i.e., 30\% manure (M30); $15 \%$ manure + $15 \%$ paper waste (MP 30); MP30 + $3 \mathrm{~mL}$ BS4 enzyme equal to 0.42 U/g dry matter (MPE30) The percentage of waste papers addition in feces was calculated on dry matter (DM) basis and every treatment had five replications. Total gas and methane productions were measured weekly, while dry matter losses were determined during 5 week fermentation. Interactions between treatments and incubation time were analyzed using completely randomized design each week. Kind of substrates influenced both total gas and methane productions during incubation time. Both waste papers and enzyme addition enhanced gas production. The highest total gas and methane productions for five weeks incubation were highly significantly observed $(\mathrm{P}<0.01)$ in MP30 and MPE30 compared to M30. Addition of enzyme significantly increased total gas and methane productions in the first week. The highest methane and total gas yield/g dry matter were obtained by BS4 enzyme addition. It is concluded that BS4 enzyme is good in accelerating and increasing the transformation efficiency of waste paper and manure mixture for biogas production.

Key Words: Methane, Fibrenolytic-Enzyme, Waste Papers, Cattle Manures

\section{INTRODUCTION}

Waste paper, including newspapers, is one of the types of waste that are most commonly found in the environment. In 2005, the production of waste newspaper per capita was $0.61 \mathrm{~kg} /$ capita/year, and the amount continues to increase with the growing number of population (Wahyono et al. 2011). An effort that can be done to reduce the waste paper is to recycle the waste paper into methane biogas by anaerobic digestion 
process using mixture of animal manure with waste paper as media.

Biogas is a renewal energy that can be used as an alternative to meet the fuel needs. The raw material of this energy source is a non-fossil material, generally from an organic waste such as animal manures. The use of methane biogas as a fuel substitute for LPG (Liquefied Petroleum Gas) is already quite extensive. The anaerobic digestion of organic waste materials also solve the pollution problem caused by abundant waste material.

In Mumbai, India, local household waste treatment with biogas reactor has been implemented since 1903 (Nijaguna 2002). The biogas is generally composed of methane $\left(\mathrm{CH}_{4}\right) 53-70 \%, \mathrm{CO}_{2}(30-47 \%), \mathrm{N}_{2}(0.2 \%)$, and other gasses such as ammonia, hexane and $\mathrm{O}_{2}$ in very low concentrations. One source of methane emissions resulting from agriculture activity is livestock production activities. Beside rumen activity stacking of cow dung in the field allows the release of methane into the open air as a greenhouse gas that potentially involved in global warming. Its greenhouse effect is 24 times greater than $\mathrm{CO}_{2}$. On the other hand, collecting the methane as biogas is preferred because the methane has a high energy density, i.e., about 400-600 BTU/ $\mathrm{ft}^{3}$ (Folkson 2014).

Waste paper consists of organic fiber materials such as amorphous and crystalline celluloses. The crystalline cellulose is stable and difficult to be degraded by bacteria and spoilage microbes. The fibers require pretreatment processes by chemical, physically-chemical, or biological processes before it could be converted into biogas. Physical methods such as grinding and exposure to radiation; chemical methods such as addition of acids or bases; biological method such as enzymatic degradation have been reported as pretreatment methods (Baatar et al. 2014). Hydrolysis using enzymes or bio treatments has several advantages for low energy input, does not use hazard chemicals, and environmentally friendly (Sutaryo et al. 2014).

Cattle manure is usually used as a source of inoculum in the anaerobic production of methane biogas. Using newspapers waste as the substrate needs the inoculum which has some cellulolytic, hemicellulolytic and methanogenic bacteria. All types of bacteria originated from the intestinal tract of cattle are manifested in the manures. The cellulolytic and hemicellulolytic bacteria in the cattle manure transform the cellulose and hemicellulose into monosacharides such as glucose which was transformed by other bacteria into simple organic acids. These organic acids are then processed into methane by methanogenic microbes (Ofoefule et al. 2010).

BS4 enzyme a multi enzyme produced by Eupenicillium javanicum in coconut meal consist of $\beta$ D-mannanase, $\beta$-D-endoglucanase (CMCase), $\beta$ mannosidase, $\alpha$-D-galactosidase, and $\beta$-D- glucosidase. The multi enzymes have been shown synergistically degraded cellulose and hemicellulose of plant cell walls of palm kernel cake into reducing sugars (Purwadaria et al. 2003; Mirnawati et al. 2013). It is possible that BS4 can degrade cellulose of waste papers. The synergistic activity of the entire enzymes in waste paper digestion can be detected by assaying filter paper-degrading activity (Fpase).

Beside pretreatments methane biogas production can be accelerated by addition of substrates continuously. The waste products or sludge from the digester can still be used as organic fertilizer (Haryati 2006).

The research reported in this paper explored the possibility to optimize methane production from waste papers and cattle manure as the substrates and inoculum respectively with the addition of enzyme.

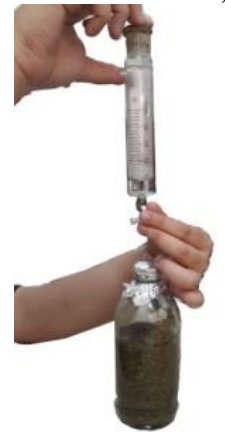

A.

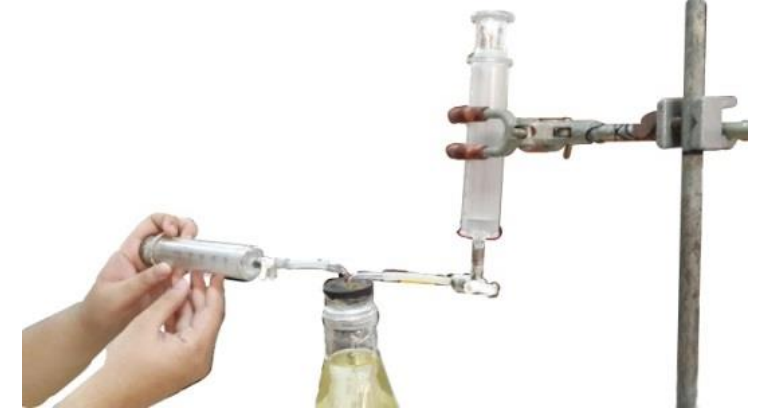

B.

Figure 1. The total gas (A) and methane (B) measuring equipments. The total gas measurement was taken directly with measured syringe, while for the measurement of methane, the gas must pass through the $0.05 \mathrm{~N} \mathrm{NaOH}$ solution flask. 


\section{MATERIALS AND METHODS}

A fresh cattle manures used as a source of inoculum was obtained from IRIAP. Old newspapers were cut with a width of $5 \mathrm{~mm}$ using a paper shredder and then chopped with a length of $10 \mathrm{~mm}$. BS4 fibernolytic enzyme used in the experiment was produced using a mold E. javanicum grown on coconut meal in solid substrate fermentation. Gas production experiment was conducted in $500 \mathrm{ml}$ glass bottles, incorporated with $\mathrm{CO}_{2}$ and closed with rubber bottle caps and reinforced with aluminum sheet. The total gases of $\mathrm{CO}_{2}$ and methane production were measured directly with measured syringe, while the methane was measured after the gas was reacted with $0.05 \mathrm{~N} \mathrm{NaOH}$ (Figure 1).

The enzyme addition was determined based on the activity of the enzyme to the filter paper (FP-ase). The amount of enzyme added was $3 \mathrm{ml}$ per bottle with the activity of $0.42 \mathrm{U} / \mathrm{g}$ DM that suitable used for feed additive containing palm kernel meal (Sinurat et al. 2007). Each treatment consisted of 5 replications.

The experiment was conducted for five weeks and samples of total gas production and methane were collected and measured weekly. After the measurement the gas in the sample bottles was relatively empty. Dry Weight Loss (DWL), the yield of total gas and methane towards DWL of each treatment were determined at the end of experiment.

Determination of FPase activity assay was carried out using a modification of the method by Mandels \& Sternberg (1976). A volume of $0.4 \mathrm{~mL}$ of enzyme sample was mixed with $1.1 \mathrm{~mL}$ of $0.05 \mathrm{mM} \mathrm{Na}$-acetate buffer at $\mathrm{pH}$ 4.8. Rolled filter paper of Whatman no.1 with a size of $1 \times 6 \mathrm{~cm}$ was added to a sample and the control solution. The sample solution was incubated at $60^{\circ} \mathrm{C}$ for 1 hour while the control solution was not incubated. DNS reagent $(3 \mathrm{ml})$ was added to a solution of the sample after incubation and directly on the control to stop the enzymatic reaction and for detection the reducing sugars produced. Samples and controls then were heated in boiled water for 15 minutes. In each test tube $5 \mathrm{~mL}$ of distilled water was added. The absorbance of the samples and the control were then measured using a UV-Vis spectrophotometer with a wavelength of $540 \mathrm{~nm}$. Spectrophotometer measurement results were compared with the control samples and the standard curve of D-glucose 300-1,800 $\mu \mathrm{g} / \mathrm{mL}$.

Dry matter (DM) contents were measured in the begining of the trial at the end of the experiment. Determination was conducted using gravimetry method after heating at $105^{\circ} \mathrm{C}$ oven for overnight.

The ratio of total gas and methane productions in five weeks with the dry matter loss (DML) were calculated to observe the efficiency of gas production for each treatment. Statistical analysis was performed to show the differences between treatments on the data obtained in each week during the five weeks of incubation. The analysis (ANOVA) was carried out using completely randomized design with 4 (four) treatments and 5 (five) replications. Least Significant Difference (LSD) test was used to evaluate significant differences between treatment when the ANOVA show a significant effect $(\mathrm{P}<0.05)$.

\section{RESULTS AND DISCUSSION}

The kind of substrates over a 5 week incubation were significantly influenced the total gas and methane productions (Table 1) in every week. Even though the dry matter of the three treatments were similar, the total

Table 1. Total gas (A) and methane (B) productions (mL/bottle) in every week during the course of fermentation A. Gas total

\begin{tabular}{|c|c|c|c|c|c|c|}
\hline \multirow{2}{*}{ Substrates } & \multicolumn{5}{|c|}{ Incubation time (weeks) } & \multirow{2}{*}{$\frac{\text { Total }}{1-5}$} \\
\hline & 1 & 2 & 3 & 4 & 5 & \\
\hline M30 & $94.0^{\mathrm{b}}$ & $124.8^{b}$ & $67.8^{b}$ & $60.4^{c}$ & 84.6 & $431.6^{b}$ \\
\hline MP30 & $203.3^{\mathrm{a}}$ & $243.7^{\mathrm{a}}$ & $-164.3^{a}$ & $115.7^{\mathrm{a}}$ & 65.7 & $783.7^{\mathrm{a}}$ \\
\hline MPE30 & $247.2^{\mathrm{a}}$ & $186.0^{\mathrm{ab}}$ & $165.6^{\mathrm{a}}$ & $76.4^{\mathrm{b}}$ & 58.4 & $733.6^{\mathrm{a}}$ \\
\hline $\mathrm{P}$ value & $<0.01$ & 0.02 & $<0.01$ & $<0.01$ & 0.23 & $<0.01$ \\
\hline
\end{tabular}

B. Methane

\begin{tabular}{|c|c|c|c|c|c|c|}
\hline \multirow{2}{*}{ Substrates } & \multicolumn{5}{|c|}{ Incubation time (weeks) } & \multirow{2}{*}{$\begin{array}{c}\text { Total } \\
1-5\end{array}$} \\
\hline & 1 & 2 & 3 & 4 & 5 & \\
\hline M30 & $25.3^{\mathrm{c}}$ & $37.3^{\mathrm{b}}$ & $22.5^{\mathrm{b}}$ & $19.5^{c}$ & $27.7^{\mathrm{a}}$ & $132.3^{\mathrm{b}}$ \\
\hline MP30 & $55.3^{\mathrm{b}}$ & $60.2^{\mathrm{b}}$ & $43.0^{\mathrm{a}}$ & $30.7^{\mathrm{a}}$ & $21.3^{\mathrm{ab}}$ & $209.2^{\mathrm{a}}$ \\
\hline MPE30 & $80.6^{\mathrm{a}}$ & $55.0^{\mathrm{ab}}$ & $39.6^{\mathrm{a}}$ & $14.4^{\mathrm{b}}$ & $9.6^{\mathrm{b}}$ & $199.2^{\mathrm{a}}$ \\
\hline $\mathrm{P}$ value & $<0.01$ & $<0.01$ & $<0.01$ & $<0.01$ & 0.02 & $<0.01$ \\
\hline
\end{tabular}

Different superscript in the same column shows significant difference. M30 was-30\% DM of manure; MP30 was $15 \%$ manure $+15 \%$ waste paper; MPE30 was MP30 + BS4 enzyme. 
gas and methane productions of MP30 and MPE30 were highly significantly higher than that of M30. The gas production during fermentation caused by the decomposition of structural carbohydrates into methane and $\mathrm{CO}_{2}$ by the activity of fibernolytic, sugars fermented and methanogenic bacteria (Ofoefule et al. 2010). The waste papers were much easier transformed into glucose and gasses than the cattle manures which already fermented and digested in the digestion track.

The pattern of gas production (Table 1) mimics the general growth curve of microbes, after adaptation the gas produced in logarithmic phase and after the maximum production is reached, the production is reduced. However, an exception was found in the enzyme supplementation treatment (MPE30) in which the highest total gas and methane production occurred in the first week due to acceleration by BS4 addition. BS4 showed filter paper activity or can transform paper into sugars. Other treatments showed the maximum total gas and methane productions occurred in the second week incubation. After that the gases were still produced, but with the lower amount. The gas production reduction occurred due to the less amount of substrate remained for further fermentation process. These results suggest that the addition of enzymes can accelerate the formation of gas so as to shorten the incubation time in the biogas production process. The cumulative amount of total gas and methane produced during incubation were calculated (Table 2) To understand how much the gas produced.

Similar to weekly gas production, the cumulative total gas and methane production were highly significantly $(\mathrm{P}<0.01)$ influenced by the treatments. Since the gasses were produced in every week resulted in the increase amount of cumulative gasses in the course of incubation. Waste papers showed significantly $(\mathrm{P}<0.05)$ better substrate for producing gasses compared to the cattle manure. The highest total gas and methane productions were observed when the BS4 enzyme was added (MPE30) or the mixture of waste paper and manures with BS4 addition on the first and second weeks, while the highest total gas was only observed in the first week. After that the effect of enzyme addition was not detected, since the cumulative amount of gasses between MPE30 and M30 were not significantly different $(\mathrm{P}>0.05)$.

The effectivity of dry matter transformation into gasses was observed by dividing the amount of products (gasses) towards dry matter loss (Table 3). The highest DML of substrate was obtained in M30 treatment with an average loss of $4.68 \mathrm{~g}$ for 5 weeks, and the lowest in MPE30 with $1.88 \mathrm{~g}$ for 5 weeks. In contrast to the DML, the highest yield of total gas and methane productions were highly significant $(\mathrm{P}<0.01)$ produced in the BS4 enzyme addition (MPE30) i.e., $391.6 \mathrm{~mL} / \mathrm{g}$ and $106.3 \mathrm{~mL} / \mathrm{g}$ respectively, and the lowest were in the
M30 (92.30 mL/g and $28.31 \mathrm{~mL} / \mathrm{g}$ respectively). These results indicated that the BS4 enzyme addition (MPE30) was the most effective in the transformation of substrate to gasses.

In the experiment the gas production was observed only for five weeks incubation, and it was still produced until the fifth week. In a review by Haryati (2008) it was reported that the process of anaerobic digestion in the continuous digester culture with the waste papers substrate takes 8 weeks at a temperature of $35^{\circ} \mathrm{C}$. A third of the biogas generated in the first week, a quarter in the second week, and the rest is produced by the third week until the eighth week. Our results showed that the decrease of gas production after three weeks of incubation was in agreement with the review.

MP30 and MPE30 produced total gas more than those produced from cattle feces substrate only at M30. Total gas and methane productions (Table 1 and 2) in the mixture of substrate treatments were higher than the cattle manure substrates because MP30 and MPE30 contained more soluble carbohydrates. Dry mass of waste papers consists of 58-95\% carbohydrate (40-55\% $18-40 \%$ cellulose and hemicellulose) (Sun \& Cheng 2002), while the dry weight of cattle manures composed of $13 \%$ carbohydrates, in the form of glucose, cellulose and hemicellulose (Aslanzadeh et al. 2011). Similar results were obtained by Ofoefule et al. (2010), which concluded that cow dung and newspapers mixed media can be used as a good medium for the production of biogas. The cattle feces $\mathrm{C} / \mathrm{N}$ ratio is $22: 1$. The addition of the waste papers which contains almost no nitrogen can increase the $\mathrm{C} / \mathrm{N}$ ratio to close the optimum value of $\mathrm{C} / \mathrm{N}$ ratio of gas production $(25: 1)$. The ratio range of carbon: nitrogen in the substrate to produce methane gas are $20: 1$ to $30: 1$ and the optimal ratio is $25: 1$ (Li et al 2011). If the ratio of carbon and nitrogen in the substrate is less than the optimal, it can affect an accumulation of short-chain organic acids or lead to the formation of ammonia gas. The accumulation of organic acid or ammonia excess can inhibit the total gas especially methane productions. Addition of an extra waste paper increased the carbon content of substrate and subsequently increasing the total gas and methane productions.

Although the addition of cattle manures reduced the $\mathrm{C} / \mathrm{N}$ ratio, the feces was needed as the inoculum for cellulolytic, hemicellulolytic, and methagonic transformation processes, the nitrogen also is needed for the bacterial growth. Most of cellulolytic bacteria found in cattle feces comes from the genus Bacteroides, those are Clostridium, Ruminococcus, and Bifidobacterium, as well as other bacteria such as Allistipes, Prevotella, and Enterococcus. Most those bacteria are obligate anaerobes that difficult to grown in aerobic condition (Dowd et al. 2008). 
Table 2. The cumulative total gas (A) and methane (B) production (mL/bottle) for 5 (five) weeks of fermentation A. Total gas

\begin{tabular}{lccccc}
\hline \hline \multirow{2}{*}{ Substrates } & \multicolumn{5}{c}{ Incubation time (weeks) } \\
\cline { 2 - 5 } & 1 & 2 & 3 & 4 & 5 \\
\hline M30 & $94.0^{\mathrm{b}}$ & $218.8^{\mathrm{b}}$ & $286.6^{\mathrm{b}}$ & $347.0^{\mathrm{b}}$ & $431.6^{\mathrm{b}}$ \\
MP30 & $203.3^{\mathrm{a}}$ & $438.0^{\mathrm{a}}$ & $602.3^{\mathrm{a}}$ & $718.0^{\mathrm{a}}$ & $783.7^{\mathrm{a}}$ \\
MPE30 & $247.2^{\mathrm{a}}$ & $433.2^{\mathrm{a}}$ & $598.8^{\mathrm{a}}$ & $675.2^{\mathrm{a}}$ & $733.6^{\mathrm{a}}$ \\
P value & $<0.01$ & $<0.03$ & $<0.01$ & $<0.01$ & $<0.01$ \\
\hline
\end{tabular}

B. Methane

\begin{tabular}{|c|c|c|c|c|c|}
\hline \multirow{2}{*}{ Substrates } & \multicolumn{5}{|c|}{ Incubation time (weeks) } \\
\hline & 1 & 2 & 3 & 4 & 5 \\
\hline M30 & $25.3^{\mathrm{c}}$ & $62.8^{c}$ & $85.1^{\mathrm{b}}$ & $104.6^{b}$ & $132.3^{b}$ \\
\hline MP30 & $55.3^{\mathrm{b}}$ & $115.7^{\mathrm{b}}$ & $158.5^{\mathrm{a}}$ & $189.2^{\mathrm{a}}$ & $209.2^{\mathrm{a}}$ \\
\hline MPE30 & $80.6^{\mathrm{a}}$ & $136.0^{\mathrm{a}}$ & $175.2^{\mathrm{a}}$ & $189.6^{\mathrm{a}}$ & $199.2^{\mathrm{a}}$ \\
\hline$P$ value & $<0.01$ & $<0.01$ & $<0.01$ & $<0.01$ & $<0.01$ \\
\hline
\end{tabular}

Different superscript in the same column shows significant difference.

M30 was-30\% DM of manure

MP30 was $15 \%$ manure $+15 \%$ waste paper

MPE30 was MP30 + BS4 enzyme

Table 3. Dry matter losses (DML) and Yield of gasses of different substrates after 5 (five) weeks of incubation

\begin{tabular}{lccc}
\hline \hline Treatment & DML $(\mathrm{g})$ & Gas Yield $(\mathrm{mL} / \mathrm{g})$ & $\mathrm{CH}_{4}$ Yield $(\mathrm{mL} / \mathrm{g})$ \\
\hline M30 & $4.68^{\mathrm{a}}$ & $92.3^{\mathrm{c}}$ & $28.3^{\mathrm{c}}$ \\
MP30 & $3.62^{\mathrm{b}}$ & $271.0^{\mathrm{b}}$ & $57.9^{\mathrm{b}}$ \\
MPE30 & $1.88^{\mathrm{c}}$ & $391.6^{\mathrm{a}}$ & $106.3^{\mathrm{a}}$ \\
P & $<0.01$ & $<0.01$ & $<0.01$ \\
\hline
\end{tabular}

Different superscript in the same column shows significant difference.

M30 was-30\% DM of manure;

MP30 was $15 \%$ manure $+15 \%$ waste paper;

MPE30 was MP30 + BS4 enzyme.

Total gas and methane productions of MPE30 was higher in the first and the second week of incubation (Table 2), however their production rate declined from the third week until the end of incubation. The enzyme activity was rather not expressed or inhibited. Inhibition of the enzyme by the reaction product can be used as a major reason fibrenolytic enzymes work cessation (Kristensen et al. 2009). Especially in the first week of incubation the carbohydrates were fastly digested into monosaccharides, some were fermented and transformed into the gasses, but some inhibited BS4 activity. Therefore in the third week until the fifth week of incubation, the addition of the enzyme did not have any significant difference in the methane productions with the one without enzyme addition (MP30). The decline of production also may be due to less available fermentable substances.
The addition of the enzyme in the treatment MPE30 improves production efficiency and methane gas. Samples with treatment MPE30 able to produce the amount of gas in total $(733.0 \mathrm{~mL})$ and methane $(199.2$ $\mathrm{mL}$ ) using the least substrate at $1.88 \mathrm{~g}$ (Table 2 and 3 ) producing the highest yield of $391.6 \mathrm{~mL} / \mathrm{g}$ and 106.3 $\mathrm{mL} / \mathrm{g}$ respectively. As a comparison, MP30 treatment required almost double the amount of dry substrate $(3.62 \mathrm{~g})$ to produce same amount of gas and methane. Increased yield of methane in the digestion is also found in the study of solid waste digestion by Roman et al. (2006). From these results, it is concluded that the addition of hydrolase enzymes accelerated the fermentation process and enhanced the effectivity of transformation. Although the formation of gas in the treatment with the addition of enzyme resemble the treatment without the addition of enzymes, fermented 
waste organic materials can still be used for organic fertilizer. The time for addition of the enzyme may also noteworthy because report of Sutaryo et al. (2014) showed that the addition of multienzyme into the composite substrate dairy cattle manure (DCM) at the pre-treatment stage provide results that significantly increased $(4.15 \%)$ methane production compared to the control without the addition of enzymes into anaerobic digester. In this experiment the addition of enzyme only arranged at one dose and it already accelerated the gasses production in the first week of incubation. Less dosage of enzyme activity might slower the transformation of the carbohydrates into monosaccharide just enough for the VFA fermentation and methane production resulted the protection of feedback inhibition occurred for more methane production. The addition of BS4 enzyme proved that the biogas production could accelerate or lesser time of fermentation is required to produce the gasses. Large scale operation should be designed for field application. The enzyme addition might be applied with continuous substrate feeding which may enhance the biogas production.

Utilization of dung cow manure with the addition of agricultural waste or agricultural residues has been widely applied to biogas production. The use of waste paper and the addition of enzymes can be added as an alternative to accelerate anaerobic digestion to obtain more efficient results.

\section{CONCLUSION}

Results in this study showed that newspapers waste can be used as a carbon source and a good substrate for biogas production of methane after mixed with cattle manures. The addition of fibrenolytic enzyme from $E$. javanicum BS4 into the substrate increased the production of methane in the first two weeks of incubation. The addition of the BS4 enzyme can enhance the gas yield towards substrate or dry matter loss or improve the efficiency of waste papers transformation into methane or biogas as renewable energy. The use of enzymes in the incubation process can accelerate the formation of biogas so as to shorten the incubation time.

\section{REFERENCES}

Aslanzadeh S, Taherzadeh MJ, Horváth IS. 2011. Pretreatment of straw fraction of manure for improved biogas production. Bio Resourc. 6:5193-5205.

Baatar JA, Panico A, Esposito G, Pirozzi F, Lens PNL. 2014. Pre-treatment methods to enhance anaerobic digestion of organic solid waste. Appl Energy. 123:143-156.
Folkson R. 2014. Alternative fuels and advanced vehicle technologies for improved environmental performance: Towards zero carbon transportation. Waltham: Woodhead.

Dowd SE, Callaway TR, Wolcott RD, Sun Y, McKeehan T, Hagevoort RG, Edrington TS. 2008. Evaluation of the bacterial diversity in feces of cattle using 16s rDNA bacterial tag-encoded FLX amplicon pyrosequencing (bTEFAP). BMC Microbiol. 8:125. doi: 10.1186/14712180-8-125.

Haryati T. 2006. Biogas: Limbah peternakan yang menjadi sumber energi alternatif. Wartazoa. 16:160-169.

Kristensen JB, Felby C, Jorgensen H. 2009. Yielddetermining factors in high-solids enzymatic hydrolysis of lignocellulose. Biotechnol Biofuels. 2:11. doi: 10.1186/1754-6834-2-11.

Li Y, Park SY, Zhu J. 2011. Solid-state anaerobic digestion for methane production from organic waste. Renew Sustain Energy Rev. 15:821-826.

Mandels M, Sternberg D. 1976. Recent advances in cellulase technology. J Ferment Technol. 54:267-286.

Mirnawati, Djulardi A, Marlida Y. 2013. Improving the quality of palm kernel cake through fermentation by Eupenicillium javanicum as poultry ration. Pak J Nutr 12:1085-1088.

Nijaguna BT. 2002. Biogas technology. New Delhi (India): New Age International.

Ofoefule AU, Nwankwo JI, Ibeto CN. 2010. Biogas production from paper waste and its blend with cow dung. Adv Appl Sci Res. 1:1-8.

Purwadaria T, Nirwana N, Ketaren P, Pradono DI, Widyastuti Y. 2003. Synergistic activity of enzyme produced by Eupenicillium javanicum and Aspergillus niger NRRL337 on palm oil factory wastes. Biotropia. 20:110 .

Roman HJ, Burgess JE, Pletschke BI. 2006. Enzyme treatment to decrease solids and improve digestion of primary sewage sludge. Afr J Biotechnol. 5:963-967.

Sinurat AP, Purwadaria T, Bintang IAK, Pasaribu T. 2007 Peningkatan nilai gizi solid heavy phase dalam ransum unggas sebagai pengganti jagung. JITV. 12:87-95.

Sun Y, Cheng J.2002. Hydrolysis of lignocellulosic materials for ethanol production: a review. Bioresour Technol. 83:1-11. doi: 10.1016/S0960-8524(01)00212-7.

Sutaryo S, Ward AJ, Moller HB. 2014. The effect of mixedenzyme addition in anaerobic digestion on methane yield of dairy cattle manure. Environ Technol 35:24762482.

Wahyono S, Sahwan FL, Suryanto F. 2011. Membuat pupuk organik granul dari aneka limbah. Jakarta (Indones): AgroMedia Pustaka. 